\title{
TEOLOGI MAUT VS TEOLOGI PEMBEBASAN ASGHAR ALI ENGINEER
}

\author{
Oleh: \\ Rido Putra dan Amril \\ Dosen Fakultas PAI Universitas Negeri Padang (UNP) \\ Dosen Fakultas Ushuluddin UIN Imam Bonjol Padang \\ E-mail: ridhosipoetrakampai@gmail.com
}

\begin{abstract}
Abstrak
This article describes the actions of resistance carried out by groups of adherents of "theology of death". Death theology is a theology that asks to die, but does not dare to live, outside us is wrong. Indonesia as a heterogeneous country is certainly not friendly with theology of death. If this theology develops rapidly, it will not be closed to spend Pancasila as the basis of a state that has umbrella for religion which is commonly prepared to hang from the pillars of history. Death theology received a response from contemporary Muslim theologians, one of the figures being Asghar Ali Engineer from India. Engginner's ideas are famous for "liberation theology". Engineers offer three praxis agreements in theology, namely: the concept of monotheism, the concept of faith, and the concept of jihad. These three concepts lead to the values of appreciation. This finding could be implicated in the terminology of Engginner's liberation theology as an attempt to refute the inhuman death theology with this one planet.
\end{abstract}

Keywords: Death Theology, Ali Liberation Theology, Engineer Asghar, Pluralism

\section{A. Pendahuluan}

Secara normatif, tidak ada satupun agama yang menganjurkan umatnya untuk melakukan tindak kekerasan, baik terhadap sesamanya yang berbeda pandangan (mazhab) maupun pada pengikut agama lain. Sebaliknya, agama justru memerintahkan manusia untuk saling mengenal dan memahami satu sama lain (Q.S Ali Imran [3]: 64; al-Hujurat [49]: 13). Lebih dari itu, sebagaimana dinyatakan dalam sebuah statemen yang diyakini sebagai Hadis, adanya perbedaan dan pluralitas adalah rahmat, bukan laknat!

Namun, secara faktual-historis, tidak sedikit dijumpai tindak kekerasan yang dilakukan masyarakat agamis. Bahkan, ada kecenderungan bahwa kekerasan justru dilakukan oleh mereka yang bisa dikatakan mempunyai basis agama yang kuat dan melakukannya dengan atas nama agama. Apa yang terjadi pada masyarakat Sulawesi Tengah, Maluku, dan Aceh (dalam negeri), dan Aljazair, Afganistan, dan 
India (luar negeri), adalah bukti-bukti yang menyatakan hal tersebut. ${ }^{1}$

Kelompok-kelompok teror yang melakukan aksi kekerasan tersebut oleh Syafii Maarif, digelari penganut "teologi maut". Teologi maut adalah sebuah teologi yang mengajarkan bahwa berani mati, tapi tidak berani hidup. Di luar kami adalah salah. ${ }^{2}$ Bila penganut teologi ini dibiarkan berkembang, maka Indonesia sebagai negara heterogen tentu saja lambat laun akan menghembuskan nafas terakhir sebagai negara Pancasila yang memayungi pluralitas agama di dalamnya.

Kenyataan-kenyataan yang pahit tersebut akhirnya mendorong para pemikir untuk menemukan konsep alternatif dan menyajikan agama yang sejuk serta damai, sehingga muncul gagasan dan sikap-sikap keberagaman yang dikenal dengan istilah inklusivisme. Di Indonesia, sikap ini antara lain tampak, misalnya pada Nurcholish Madjid yang dikenal dengan kalimatun sawa'. Di sini Nurcholish menyatakan bahwa meski agama-agama yang ada adalah berbeda tetapi mereka mempunyai titik temu yang sama, yaitu bahwa semua mengarah dan bersumber pada Yang Esa, sehingga masing-masing komunitas agama tidak perlu menuding

${ }^{1}$ Rido Putra, "Pemikiran Farid Esack tentang Hermeneutika Pembebasan" dalam Abdul Mustaqiem (ed.), Studi al-Qur'an dan Hadis Perspektif Teks dan Konteks (Yogyakarta: FA Press, 2018), h. 131-132.

2 Istilah "teologi maut" ini sering digaungkan oleh Syafii Maarif pada forumforum seminar dan juga di dalam tulisantulisannya. Dewi Irmasari, https://news.detik.com/berita/d-3468925/buyasyafii-bicara-soal-suriah-irak-dan-teologi-maut, diakses 5 November 2019. pihak lain salah dan menganggapnya sebagai lawan.

Begitu juga dengan Asghar Ali Engineer (selanjutnya disebut Engineer), seorang pemikir dan teolog asal India yang hidup pada situasi dan kondisi masyarakat Muslim India yang marjinal, terkebelakang, tradisional, dan sikap defensif-konservatif dalam menghadapi realitas. Dengan melihat dan merasakan langsung kondisi seperti itu, Engineer mencoba melakukan perubahan melalui gagasannya yang dikenal dengan "teologi pembebasan". Ia mencoba merumuskan dan menyodorkan tiga kerangka praksis di antaranya: konsep tauhid, konsep iman, dan konsep jihad yang semuanya bermuara pada nilainilai kemanusiaan.

Sehubungan dengan itu, dalam tulisan ini akan bahas seperti apa teologi pembebasan Engineer bekerja, dan bagaimana relevansi teologi pembebasan Engineer dengan pluralis agama di Indonesia?

\section{B. Paradigma Teologi Islam}

Setelah Nabi Muhammad saw. wafat, terjadilah perubahan dengan timbulnya perebutan kekuasaan yang berorientasi kepada kepentingan pribadi dan golongan. Kemudian tampillah orang-orang yang menginginkan status quo, sehingga Islam menjadi hilang daya revolusioner yang telah dimilikinya sampai sedemikian jauh. Sejak itulah, perhatian umat lebih tercurah pada masalah-masalah teologi, ketimbang masalah sosial dan ekonomi. Kondisi ini ditambah lagi dengan persinggungan antara Islam dan ilmu pengatahuan Yunani, yang tentunya dapat menimbulkan dampak positif dan 
negatif. Di samping itu, kalangan elit Islam semakin bersemangat untuk melakukan intellectual exercise yang bersifat spekulatif. Selanjutnya, Islam yang revolusioner itu menjadi hilang vitalitasnya. Sekolah-sekolah teologi dan hukum mulai menancapkan eksistensinya, dan bersamaan dengan itu, Islam kurang memperdulikan masalah-masalah keadilan sosioekonomi. Umat Islam hanya menyisakan sedikit rasa peduli terhadap golongan yang lemah, dan lenyapnya elan vital keadilan Islam yang distributif. ${ }^{3}$

Selama ini dikenal dua paradigma teologi yang masih berlaku di dunia Islam, yakni paradigma Asy'ariyah dan Salafiyah. Paradigma Asy'ariyah lebih banyak penganutnya daripada paradigma Salafiyah. Sementara paradigma Asy'ariyah dan Salafiyah saling berebut pengaruh, hal ini memunculkan paradigma kritis Engineer yang menginginkan adanya paradigma baru dalam teologi, yang tujuannya jelas-jelas membela masyarakat yang tertindas. Paradigma ini menggagas sebuah paradigma teologi yang lebih memihak kaum bawah, yang kemudian dikenal dengan teologi pembebasan. ${ }^{4}$

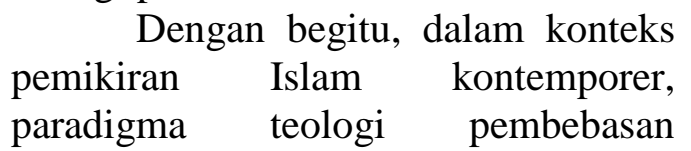
mencuat kepermukaan sebagai sebuah keniscayaan sejarah. Paradigma ini muncul seiring dengan adanya fenomena sosial berupa ketinggalan,

3 Asghar Ali Engineer, Islam dan Teologi Pembebasan, Terj. Agung Prihantoro (Yogyakarta: Pustaka Pelajar, 2003), h. x.

${ }^{4}$ Muhyar Fanani, Metode Studi Islam Aplikasi Sosiologi Pengetahuan sebagai Cara Pandang (Yogyakarta: Pustaka Pelajar, 2008), h. 143 . kemiskinan, ketidakadilan, keterbelakangan, dan kebodohan masyarakat Islam dibandingkan masyarakat non Islam lainnya. Banyak pemikir Islam kontemporer merasa gelisah dan berusaha mencari penyelesaian atas realitas yang sedang dihadapi masyarakat Islam tersebut. Dalam konteks ini, dikenal pemikirpemikir seperti Hasan Hanafi yang mencetuskan ide al-Yasar al-Islami (1981), Ziaul Haque dengan Revelation and Revolution (1992), dan Asghar Ali Engineer dengan Islam and Liberation Theology (1990). ${ }^{5}$

\section{Sketsa Biografi: Mengenal Lebih Dekat Sosok Asghar Ali Engineer dan Karya-karyanya.}

Engineer lahir pada 10 Maret 1939 di Rajasthan di daratan India, dalam sebuah keluarga yang berafiliasi kepada paham Syi'ah Ismailiyah ${ }^{6}$. Engineer lahir dari keluarga santri. Ia belajar bahasa Arab dari Ayahnya, syekh Qurban Husin dan mendapatkan pendidikan sekuler hingga memperoleh gelar sarjana teknik sipil dari Universitas of Indore. Dalam perjalanan hidupnya, Engineer sendiri pernah menjadi pemimpin komunitas Syiah Ismailiyah Bohra yang cukup terkenal di India. Di samping itu, Engineer pernah menjabat Sekretaris Jenderal Dewan Pimpinan Komunitas Daudi Bohras (1977), pendiri Institut of

${ }^{5}$ Muhammad In Am Esha, Rethinking Kalam: Sejarah Sosial Pengetahuan Islam, Mecermati Dinamika dan Arus Perkembangan Kalam Kontemporer (Yogyakarta: eLSAQ Press, 2006), h. 73.

6 M. Agus Nuryatno, "Asghar Ali Engineer: Sang Teolog Pembebasan”, dalam http://www.mailarchive.

com/kmnu2000@yahoogroups.com/msg01, h. 1. 
Islamic Studies di Mumbai (1980), dan ikut mendirikan Center for the Study of Society and Secularism (1993). ${ }^{7}$

Untuk lebih jauh memahami latar belakang keagamaan Engineer, ada baiknya diketahui sepintas tentang kelompok Daudi Bohras ini. Para pengikut Daudi Bohras dipimpin oleh Imam sebagai pengganti Nabi yang dijuluki Amir al-Mukminin. Mereka mengenal 21 orang Imam. Imam mereka yang terakhir adalah Maulana Abu al-Qasim al-Thayyib yang menghilang pada tahun $526 \mathrm{H}$. Akan tetapi mereka masih percaya bahwa ia masih hidup hingga sekarang. Kepemimpinannya dilanjutkan oleh para da'i (berasal dari ungkapan Daudi) yang selalu berhubungan dengan Imam terakhir itu. Untuk diakui sebagai da'i tidaklah mudah. Ia harus mempunyai 94 kualifikasi yang disimpulkan menjadi 4 kualifikasi, yaitu: pendidikan, administrasi, moral dan teoritikal, keluarga dan kepribadian. Yang menarik bahwa di antara kualifikasi itu seorang da'i harus tampil sebagai pembela umat yang tertindas dan berjuang melawan kezaliman. Untuk itu Engineer diakui sebagai seorang da'i. ${ }^{8}$

Selain Engineer yang diakui sebagai da'i, ia juga sebagai seorang ilmuan terkenal yang menguasai banyak bahasa, di antaranya bahasa Inggris, Urdu, Arda, Persia, Gujarat,

7 Nugroho Dewanto dan Iqbal Muhtarom, "Anti MUI: Islam Yes, MUI No, Surga Bukan Monopoli Muslim", Wawancara dengan Asghar Ali Engineer, Majalah Tempo, 20 Agustus 2008, h. 6.

${ }^{8}$ Djohan Effendi, "Memikirkan

Kembali Asumsi Pemikiran Kita", Kata Pengantar: Asghar Ali Engineer: Islam dan Pembebasan, dalam http://media.isnet.org/islam/Etc/Pengantar, h. 2.
Hindu dan Marathi. Engineer banyak memberikan kuliah di berbagai universitas terkenal, seperti di Pakistan, Hongkong, Amerika Serikat, Yaman, Kanada, Inggris, Swiss, Thailand, Malaysia, Mesir dan Srilangka. ${ }^{9}$ Pada bulan Agustus tahun 2008, Engineer pernah berkunjung ke Indonesia, dan menyampaikan ceramah tentang Islam dan Negara Bangsa, serta bertemu dengan sejumlah cendekiawan Islam Indonesia, salah satunya adalah Abdurrahman Wahid. ${ }^{10}$

Sebagai seorang pemikir yang hebat, Engineer telah menerbitkan puluhan buku dengan berbagai tema, di antaranya adalah: The Oringin and Development of Islam, On Developing Liberation Theology in Islam, Islam and Its Relevance to Our Age, Islam and Muslims: Critical Perspectives, Seminar on Sufism and Communal Harmony, The Bohras, The Islamic State, Women and Modern Society. Islam and Liberation Theology, Islam in South-East Asia, The Spirituality of Social Movement, Rights of Women in Islam, Ethnic Problem in South Asia, The Qur'an, dan Communalism and Communal Violence in India. Selain itu Engineer juga menulis beberapa artikel beberapa surat kabar terkemuka di India, seperti Indian Express, The Hindu Daily, Times of India, Telegraph, dan Indian Jurnal of Secularism. ${ }^{11}$

\section{Jamal Syarif, "Pemikiran Asghar Ali} Engineer Tentang Hak-Hak Perempuan dalam Islam", Khazanah Jurnal Ilmiah Keislaman dan Kemasyarakatan, Vol. III, No.1, JanuariPebruari 2004, (Banjarmasin: IAIN Antasari, 2004), h. 103.

${ }^{10}$ Nugroho Dewanto dan Iqbal Muhtarom, Anti MUI.., h. 1.

${ }^{11}$ Muhammad In Am Esha, Rethinking Kalam.., h. 78. 
Djohan Effendi tampak sangat tertarik terhadap pemikiran Engineer. Menurut Djohan, Engineer adalah seorang mukmin sejati, bukanlah sekedar orang yang percaya kepada Allah akan tetapi juga ia seorang mujahid yang berjuang menegakkan keadilan, melawan kezaliman dan penindasan. ${ }^{12}$

Di luar aktivitas intelektualnya, Engineer adalah seorang aktivis sosial. Di antara jabatan penting yang diembannya antara lain: Ketua pendiri pada Centre for Study of Society and Secularism, Wakil Presiden pada People's Union for Civil Liberties, Pemimpin Rikas Adhyayan Kendra (Centre for Development Studies), Pemimpin EKTA, (Committee for Communal Harmony), Mantan Dewan Eksekutif Universitas of Jawaharlal New Selhi, dan Sekretaris Umum pada Central Board of Dewood di Bohra Community and Cenvenor Asian Muslim Action Network (AMAN). ${ }^{13}$

Karena pemikiran dan aktivitas sosialnya, Engineer mendapatkan beberapa penghargaan, antara lain: Gelar kehormatan D.Lit. dari Universitas Calcuta, National Communal Harmony Award dari National Foundation for Communal Harmony, Harmony Award dari New Leaders Commitee, Chennai, dan Hakim Khan Sur Award dari Maharana Mewar Foundation, Udaipur, Rajasthan. $^{14}$

${ }^{12}$ Ahmad Gaus AF, Sang Pelintas Batas Biografi Djohan Effendi (Jakarta: ICRP dan Kompas, 2009), h. 313.

13 Asghar Ali Engineer, Hak-hak Perempuan dalam Islam, Terj. Farid Wajidi (Yogyakarta: Pustaka Pelajar, 2000), h. 295.

${ }^{14}$ Muhammad In Am Esha, Rethinking

Kalam.., h. 79.

\section{Teologi Pembebasan Asghar Ali Engineer}

Pada sebuah artikel yang berjudul "What I Belive" (Mumbay: 1999), Engineer mengemukakan tiga pokok persoalan yang mendasari pemikiran-pemikirannya. Pertama, mengenai hubungan antara akal dan wahyu yang saling menunjang. Kedua, mengenai pluralitas dan diversitas agama sebagai keniscayaan. Ketiga, mengenai watak keberagamaan yang tercermin dalam sensitivitas dan simpati terhadap penderitaan kelompok masyarakat lemah.

Pokok-pokok pemikiran di atas inilah yang melandasi Engineer dalam mengkonstruksi teologi pembebasan dalam Islam, sebagaimana yang ia tunjukkan dalam bukunya Islam and Liberation Theology (1990). Menurut Engineer, teologi klasik cenderung kepada masalah-masalah yang abstrak dan elitis, berbeda dengan teologi pembebasan lebih cenderung kepada hal-hal yang konkret dan historis, dimana tekanannya ditujukan kepada realitas kekinian, bukan realitas di alam maya. Bagi Engineer, teologi tidak hanya bersifat transendental, tetapi juga kontekstual. Teologi yang hanya berkutat pada wilayah metafisik akan tercerabut dari akar tunggang sosialnya. Baginya, teologi adalah refleksi dari kondisi sosial yang ada, dan dengan demikian suatu teologi adalah dikonstruksi secara sosial.

Bagi Engineer, pandangan teologi tidak netral. Ia mempunyai keberpihakan, apakah kepada status quo atau kepada perubahan. Dengan kata lain, teologi dapat menjadi instrumen pembebas atau pembelenggu manusia. Ibarat dua mata pisau. Semua tergantung kepada siapa yang mengkonstruksi dan menggunakannya. 
Keberpihakan teologi pembebasan sangat jelas, yaitu kepada mereka yang lemah dan tertindas. Ia diproyeksikan untuk perubahan, bukan untuk mengabdi kepada kekuasaan dan status quo. ${ }^{15}$ Menarik apa yang disampaikan Engineer bahwa, "teologi bisa menjadi instrumen pembebas dan pembelenggu manusia". Bagi penganut teologi maut, sadar atau tidak sadar, ia sedang dibelenggu oleh pemahamannya yang dapat mengikis nilai-nilai kemanusiaan.

Jadi teologi pembebasan yang dipelopori Engineer merupakan usulan kreatif yang mengaitkan antara pentingnya paradigma baru dalam teologi yang memerangi penindasan dalam struktur sosio-ekonomi. Paradigma ini dilatarbelakangi oleh banyaknya fenomena arogansi kekuasaan, ketidak adilan, penindasan terhadap kaum lemah, pengekangan terhadap aspirasi masyarakat banyak, diskriminasi kulit, bangsa atau jenis kelamin, penumpukan kekayaan, kekerasan atas nama agama, dan pemusatan kekuasaan dalam realitas masyarakat kontemporer. ${ }^{16}$

Menurut Engineer, Islam adalah sebuah agama dalam pengertian teknis dan sebagai pendorong revolusi sosial yang memerangi struktur yang menindas. Tujuan dasarnya adalah persaudaraan yang universal (universal brotherhood), kesetaraan (equality) dan keadilan sosial (social justice). ${ }^{17}$ Oleh sebab itu, teologi pembebasan dilatarbelakangi tidak hanya masalah sosio-ekonomi dan psiko-sosial, tetapi juga cocok dihadapkan dengan kelompok yang menganut kebenaran

\footnotetext{
${ }^{15}$ M. Agus Nuryatno, Asghar Ali Engineer.., h. 2.

${ }^{16}$ Muhyar Fanani, Metode Studi Islam.., h. 150.

${ }^{17}$ Asghar Ali Engineer, Islam.., h. 3.
}

tunggal. Struktur sosial saat ini sangat menindas dan harus diubah, sehingga menjadi lebih adil dengan perjuangan yang sungguh-sungguh, optimis, membutuhkan kesabaran yang luar biasa, dan keyakinan yang kuat. ${ }^{18}$ Sebab secara psikologis, masyarakat yang hidup dalam lingkungan yang menindas akan cenderung frustrasi, pesimis, suka jalan pintas, dan lemah keyakinan. Kondisi psikis semacam ini harus diatasi dengan munculnya keyakinan teologis yang kuat agar mendorong mereka untuk giat mengubah nasibnya sendiri tanpa rasa frustrasi, dan menjadikan sumber motivasi kaum tertindas untuk mengubah keadaan mereka dan menjadikan kekuatan spiritual untuk mengomunikasikan dirinya secara berarti dengan memahami aspek-aspek spiritual yang lebih tinggi. ${ }^{19}$

Untuk itulah, teologi pembebasan sangat menekankan pada aspek praksis, yaitu kombinasi antara refleksi dan aksi, iman dan amal. Ia merupakan produk pemikiran yang diikuti dengan praksis untuk pembebasan. Jadi teologi pembebasan berupaya untuk menjadikan mereka yang lemah dan tertindas menjadi makhluk yang independen dan aktif. Karena hanya dengan menjadikan manusia yang aktif dan merdeka, mereka dapat melepaskan diri dari belenggu penindasan. ${ }^{20}$

Sumber inspirasi teologi pembebasan menurut Enginer adalah al-Qur'an dan sejarah para rasul dan Nabi Allah. Keberpihakan kedua sumber ini kepada kaum lemah tidak diragukan lagi. Al-Qur'an dengan jelas

\footnotetext{
${ }^{18}$ Asghar Ali Engineer, Islam.., h. 12.

${ }^{19}$ Muhyar Fanani, Metode Studi Islam.., h. 151.

${ }^{20}$ M. Agus Nuryatno, Asghar Ali Engineer.., h. 2.
} 
mengajarkan untuk menyantuni anakanak yatim, orang-orang lemah, menegakkan keadilan, dan menekankan agar kapital tidak hanya berputar- putar disegelitir orang. Penekanan demikian persis yang dipraktekkan oleh para rasul dan nabi Allah. $^{21}$

Dalam pandangan Engineer, para sejarawan membuktikan bahwa nabi Muhammad sebagai utusan Allah menggulirkan tantangan yang membahayakan saudagar-saudagar kaya suku Quraisy, yang berasal dari suku yang berkuasa di Mekah. Penolakan masyarakat Quraisy terhadap dakwah nabi Muhammad, menurut Engineer lebih dikarenakan faktor ekonomi daripada faktor agama. Masyarakat Quraisy yang menentang takut jika hegemoni ekonomi yang ada di genggaman mereka terganggu. Mereka menyombongkan diri dan mabuk dengan kekuasaan, melanggar norma-norma kesukuan, dan tidak menghargai fakir miskin. ${ }^{22}$ Mengikuti pemikir Mesir Taha Husein, Engineer mengatakan bahwa jika nabi Muhammad hanya mendakwahkan Islam tentang keesaan Tuhan, tanpa menyerang sistem sosial-ekonomi, mengabaikan perbedaan antara yang kuat dan yang lemah, yang kaya dan yang miskin, tuan dan budak serta tidak mendesak para konglomerat Mekah untuk mendistribusikan sebagian kekayaan mereka kepada kaum lemah dan fakir miskin, maka mayoritas masyarakat Quraisy akan menerima kehadiran Islam yang didakwahkan oleh nabi Muhammad saw. pada saat

${ }^{21}$ M. Agus Nuryatno, Asghar Ali Engineer.., h. 2.

${ }^{22}$ Asghar Ali Engineer, Islam.., h. 4. itu. $^{23}$ Dalam hal ini Engineer mengutakan keadilan sosial. Sebab, tindak kekerasan atas nama agama, kata Syafii Maarif, juga dipicu karena sila kelima dari Pancasila yaitu, keadilan sosial bagi seluruh rakyat Indonesia, belum betul-betul membumi.

\begin{tabular}{llr}
\multicolumn{1}{c}{ Dalam semangat } & $\begin{array}{r}\text { teologi } \\
\text { pembebasan ini, }\end{array}$ \\
Engineer \\
mentransformasikan tiga
\end{tabular} kerangka praksis teologi pembebasan, yaitu: pertama, konsep tauhid. Bagi Engineer, tauhid tidak hanya mengacu pada ke-Esaan Allah, namun juga pada kesatuan manusia (unity af mankind). Kesatuan bukan saja mengenai perkara akidah, tetapi adalah kesatuan dalam keadilan yang melintasi batas-batas keyakinan. Untuk itulah, dalam masyarakat tauhidi, tidak akan membenarkan dikriminasi, baik dalam bentuk ras, agama, kasta ataupun kelas sosial, sebab pembagian kelas, secara tidak langsung, menegaskan dominasi yang kuat atas yang lemah, kelas yang satu menindas yang lain, ketidakadilan, tirani, dan penindasan. Dominasi inilah yang menghalangi upaya pembentukan masyarakat yang adil. ${ }^{24}$ Lebih lanjut menurut Engineer, persoalan penindasan itu bukanlah persoalan antar pemeluk agama, akan tetapi lebih merupakan persoalan persoalan antara "penindas" dengan "yang tertindas". Sosok "penindas" dan "yang ditindas" itu bisa berasal dari agama manapun, ras apapun dan suku manapun. Dengan demikian, tauhid itu tidak hanya berdimensi sosial-ekonomi. Jelas bahwa gagasan teologi pembebasan Engineer ini bersifat universal, apapun

\footnotetext{
${ }^{23}$ M. Agus Nuryatno, Asghar Ali Engineer.., h. 2.

${ }^{24}$ Muhammad In Am Esha, Rethinking

Kalam.., h. 91.
} 
agamanya, kalau dia melakukan penindasan dalam aspek apapun, wajid dilawan.

Kedua, konsep iman. Menurut Engineer kata iman berasal dari kata amn yang berarti selamat, damai, perlindungan, dapat diandalkan, terpercaya dan yakin. ${ }^{25}$ Untuk itu, iman tidak hanya soal kepercayaan kepada Allah, tetapi orang yang beriman harus dapat dipercaya, berusaha menciptakan kedamaian dan ketertiban, dan menyakini nilai-nilai kebaikan dalam kehidupan. Iman kepada Allah akan mengantarkan manusia pada perjuangan yang sungguh-sungguh untuk menciptakan masyarakat yang adil dan sejahtera. Jadi iman tidak hanya berkutat pada wilayah keyakinan an sich, tetapi juga mengandung dimensi sosiologis dan ekonomis. Lebih lanjut menurut Engineer, orang kafir (kufr), adalah orang yang tidak hanya menampik eksistensi Allah, tetapi juga yang menantang usahausaha jujur untuk membentuk masyarakat, menghapus akumulasi dalam segala bentuknya. "Seseorang yang secara formal beriman kepada Allah, tetapi memperturutkan hawa nafsu dengan menimbun kekayaan dengan menindas orang lain, dan gemar melakukan konsumtif yang menyolok mata, sementara yang lain menderita kelaparan, juga termasuk kafir (kufr)." tegas Engineer. ${ }^{26}$

Ketiga, konsep jihad. Jihad makna literernya perjuangan. ${ }^{27}$ Teologi pembebasan memaknai jihad sebagai

\footnotetext{
${ }^{25}$ Asghar Ali Engineer, Islam.., h. 12.

${ }^{26}$ Muhammad In Am Esha, Rethinking Kalam.., h. 93.

27 Atabik Ali dan Ahmad Zuhdi Muhdlor, Kamus Kontemporer Arab-Indonesia (Yogyakarta: Multi Karya Grafika, 1998), h. 702.
}

perjuangan menghapus eksploitasi, korupsi, dan berbagai bentuk kezaliman dan kekerasan. Perjuangan yang harus dilakukan secara dinamis dan istiqamah, agar kelaliman yang dilakukan manusia sirna dari muka bumi. Untuk itu teologi pembebasan tidak memaknai jihad sebagai perang militer, tetapi aktivitas dinamis progresif untuk melakukan pembebasan masyarakat dari realitas penindasan yang menimpa mereka. Jihad untuk pembebasan, bukan jihad untuk berperang (aggression). ${ }^{28}$ Dengan demikian, menurut Engineer jihad tidak hanya dipahami untuk berperang. Indonesia sebagai negara yang penduduknya majemuk jelas tidak cocok dengan pemahaman yang seperti itu. Jika pemahaman teologi maut tersebut tetap dipaksakan, maka pertumpahan darah antar maupun sesama pemeluk agama akan terus terjadi dimana-mana. Dan, pada akhirnya Indonesia sebagai rumah bersama tak lagi nyaman untuk dihuni.

\section{E. Relevansi Teologi Pembebasan Asghar Ali Engineer dengan Pluralitas Agama di Indonesia}

Teologi pembebasan merupakan teologi yang menerima tauhid tidak sekedar sebagai peryataan tentang ke-Esaan Allah namun juga kesatuan manusia dalam semua hal. ${ }^{29}$ Konsep dasar tauhid bukan hanya menjadi doktrin metafisis, namun juga menjadi prinsip, yaitu kesatuan seluruh manusia yang diciptakan oleh Allah.

\footnotetext{
${ }^{28}$ Muhammad In Am Esha, Rethinking Kalam.., h. 92.

29 Asghar Ali Engineer, Islam and Its Relevansi to Our Age, terj. Hairus Salim dan Imam Baehaqi (Yogyakarta: LkiS, 1993), h. 94.
} 
Teologi pembebasan, atas dasar tauhid, meletakkan semua manusia secara sama kedudukannya di hadapan Allah dan di antara sesamanya. ${ }^{30}$ Pemahaman konsep tauhid Engineer ini sangat cocok dengan Indonesia yang beragama agama di dalamnya. Siapa saja yang sepemahaman dengan konsep tauhid Engineer ini tentu ia akan memanusiakan manusia tanpa melihat dulu agama apa yang dianut orang lain.

Jika manusia berbeda-beda, maka mereka tidak dikelompokkan atas dasar,

kebangsaan, suku, dan ras, dan bukan untuk saling bermusuhan serta menghancurkan kedamaian dan keharmonisan, namun keberagaman ini menjadi sarana untuk mengidentifikasi diri dan saling mengenal.

Nilai keadilan yang mendasari teologi pembebasan Enginer adalah nilai komprehensif; ia meliputi semua aspek kehidupan umat, terutama keadilan ekonomi, politik, dan sosial. Ibnu Taymiyyah, seperti dikutip oleh Engineer, menganggap keadilan itu sangat sentral dalam Islam dengan mengatakan; "Kehidupan manusia di bumi ini akan lebih tertata dengan sistem yang berkeadilan walau disertai dengan suatu perbuatan dosa, daripada dengan tirani yang 'alim".

Agama adalah fenomena spiritual manusia, maka dari sinilah pintu dialog mulai dibuka. Spiritualitas sebagai gerbang dialog yang dibuka oleh Engineer bukanlah spiritualitas yang kering sehingga statis dan menutup gerbang itu sendiri.

30 Asghar Ali Engineer, Islam and Liberation Theology: Essays and Liberative Elements in Islam (New Delhi: Sterling Publisher Private Limited, 1990), h. 225.

${ }^{31}$ Asghar Ali Engineer, Islam and Liberation Engineer.., h. 26.
Spiritualitas itu sarat dengan nilai-nilai religius serta implikasi-implikasi etis yang sangat mendalam sehingga memungkinkan terjadinya dialog antar semua agama yang ada di Indonesia.

Teologi pembebasan Asghar Ali menetapkan, perbedaan agama tidak pernah dapat dijadikan alasan untuk menciptakan konflik sehingga menutup pintu dialog. AI-Qur'an selalu memuji mujahid (seseorang yang berjuang demi haknya) (Q.S. 4: 95). Teks "jihad" adalah pembenaran dalam melindungi orang lemah dan tertindas serta pertahanan diri terhadap agresi. Al-Qur'an menyatakan: "Bertempurlah di jalan Allah melawan orang-orang yang menentangmu, tetapi jangan memulai permusuhan. Allah tidak menyukai penyerang" (Qs. 53: 39).

Teologi pembebasan Engineer yang secara konsisten diderivasi dari Syari'ah Islam memiliki signifikansi dalam kerangka aksi bersama dengan agama-agama yang ada di Indonesia, sebagaimana muncul dalam; teologi Dalit di India, teologi Perlawanan rakyat Filipini di Filipina, teologi Minjung di Korea, dan teologi Buddhadasa di Thailand. Islam harus ditampilkan sebagai agama yang penuh dengan keterbukaan, toleransi dan respek pada agama lain dalam rangka pembuktikan signifikansi di atas.

Penampilan yang sedemikian itulah kiranya yang menjadi kerangka dasar bagi aksi pembebasan dalam Islam. Al-Qur'an menyatakan: "Untuk setiap orang di antaramu Kami tentukan jalan dan hukum, dan jika Allah berkehendak ia akan menjadikanmu satu suku, tetapi bahwa ia akan mencobamu dengan apa yang ia berikan padamu. Maka berlombalombalah dengan orang lain akan perbuatan baik" (Qs. 5: 48). Menunjuk 
pada orang kafir, al-Qur'an menegaskan: "Untukmu agamamu dan bagiku agamaku (Qs. 2: 109). "Tak ada paksaan dalam agama" (Qs. 2: 256). Jadi, bagi Engineer persoalan memandang posisi agama lain sudah selelsai, ia musti dipandang sebagai manusia yang sama-sama punya hak untuk tinggal di planet bumi yang satu ini tanpa harus seagama dengan kita. Engineer cukup bijak menciptakan benang merah dalam menghargai perbedaan.

Sejarah Asosiasi Ecumenical Ahli Teologi Dunia Ketiga, secara khusus Pieris pada tahun 1919, membentangkan realitas Asia tidak hanya pada kondisi sosial masyarakatnya yang penuh dengan kemiskinan, tetapi juga religiusitasnya. Pieris juga menunjukkan, betapa nilainilal religius telah dijadikan sebagai dasar orientasi dalam penghapusan praktek-praktek pemaksaan, pemiskinan, dan penindasan di Asia. ${ }^{32}$ Tentu saja Indonesia termasuk di dalamnya. Dengan cara ini, ia menyoroti peranan positif agama dalam pembebasan di saat orang cenderung melihat hanya pada dampak pengasingan dari agama. Pesan posiitif pada masing-masing agama itu pada prinsipnya sudah jelas-jelas ada. Bahwa misi dan muara dari agama adalah membawa kedamaian bagi mahkluk sejagat.

Basis pembebasan sosial tersebut melupakan visi baru dunia dan humanitas serta sistem nilai baru yang berdasar padanya. Visi baru memunculkan Budaya baru. Budaya baru kemudian menemukan inspirasi dari dalam agama dan ideologi serta

${ }^{32}$ Aloysius Pieris, An Asian Theology of Liberation (New York: Orbis Books Maryknoll, 1988), h. 23. secara pasti ditimbulkan oleh pengalaman adanya ketidakadilan dan penindasan. Banyak aksi pembebasan gagal karena mereka hanya mengkonsentrasikan pada satu atau sedikit dimensi nilai yang bersifat fundamental tersebut.

Tidak dapat dihindari oleh siapapun bahwa selalu ada ketegangan antara yang real, dan "yang mungkin" dalam hidup manusia. Teologi tradisional dalam mengatasi ketegangan itu, sebagaimana telah disinggung pada uraian terdahulu, selalu berkompromi pada yang real dengan menggunakan istilah-istilah al Qur'an yang mendukungnya. Teologi pembebasan sebaliknya, berusaha untuk memperkuat ketegangan itu dengan menekankan pada "yang mungkin" dan berjuang menghadapi realitas yang ada untuk menjadikannya terbuka ke arah kemungkinankemungkinan baru.

$$
\text { Manusia sebagai yang }
$$

bersangkutan sajalah yang harus mengusahakan untuk meraih yang mungkin, atau untuk terlepas dari ketidak-berdayaan. "Yang mungkin" terdapat dalam diri setiap orang. Salah satu peryataan al-Qur'an yang menegaskan hal itu adalah artinya sebagai berikut; "Sesungguhnya Allah tidak akan merubah suatu kaum hingga kaum itu sendiri melakukan perubahan".

Teologi pembebasan Engineer berdasar pada "yang mungkin". Teologi pembebasan adalah teologi yang mengusahakan untuk meningkatkan derajat kebebasan baik untuk individu maupun untuk kolektif (kelompok, masyarakat atau bangsa) dengan cara mengurangi eksploitasi ekonomi. Upaya itupun harus diwujudkan melalui dialog antar dan 
sesama umat beragama, melakukan perjumpaan untuk menepis stigma negatif terhadap agama lain, mengedapankan aspek sosial dalam kehidupan kolektif, dengan begitu, penganut teologi maut akan terkurangi di bumi Indonesia ini.

\section{F. Kesimpulan}

Dari uraian di atas penulis hendak menyimpulkan beberapa hal berikut. Pertama, Engineer dikenal sebagai sosok teolog, pemikir Islam kontemporer, dan juga seorang aktivis sosial di India, yang mempunyai perhatian besar terhadap problemaproblema sosial dan keagamaan. Situasi dan kondisi masyarakat Muslim India yang marjinal, terkebelakang, tradisional dan sikap defensifkonservatif dalam menghadapi realitas, menimbulkan keprihatinan tersendiri bagi Engineer. Ia merancang teologi pembebasan dalam konteks pemikiran Islam, di mana konstruksi pemikiran yang dibangunnya concern pada upaya pembelaan terhadap kaum tertindas dari segala aspek: ekonomi, sosial, termasuk agama.

Kedua, Pemikiran Engineer yang ditransformasikan menjadi tiga kerangka praksis teologi pembebasan, yaitu: Pertama, konsep tauhid, yang tidak hanya mengacu pada keesaan Allah, namun juga pada kesatuan manusia (unity of mankind). Masyarakat tauhidi, mengakui dan menjamin kesetaraan manusia, dan tidak akan membenarkan adanya diskriminasi dalam bentuk apapun, baik terkait ras, agama, kasta ataupun kelas sosial. Kedua, konsep iman, tidak hanya dimaknai soal percaya kepada Allah, tetapi orang yang beriman harus dapat dipercaya, berusaha menciptakan kedamaian dan ketertiban, bersungguhsungguh untuk menciptakan masyarakat yang adil dan sejahtera, dan menyakini nilai-nilai kebaikan dalam kehidupan. Ketiga, konsep jihad, yang dimaknai sebagai perjuangan yang dilakukan secara dinamis dan istiqamah, untuk menghapus berbagai bentuk kekerasan dalam beragama. Teologi pembebasan tidak memaknai jihad sebagai perang militer, atau bukan jihad untuk berperang (eggression). Dan tidak berlebihan jika dikatakan, teologi pembebasan ala Engineer ini, adalah teologi humanis, sebuah paradigma teologis dan praksis bagi pembebasan manusia dalam melawan teologi maut.

Ketiga, relevansi teologi pembebasan Engineer dengan pluralitas agama di Indonesia terlihat dari tiga kerangka praksis yang ia sodorkan: konsep tauhid, konsep iman, dan konsep jihad yang bermuara pada misi kemanusiaan. Indonesia sebagai negara mayoritas penduduknya Islam tentu membutuhkan pengalaman intelektual seperti Engineer ini, mengingat banyaknya kelompok-kelompok penganut "teologi maut" yang melakukan teror karena keliru dalam menafsirkan konsep jihad, misalnya.

\section{Daftar Kepustakaan}

Ali Atabik, Ahmad Zuhdi Muhdlor. Kamus Kontemporer ArabIndonesia Yogyakarta: Multi Karya Grafika, 1998.

\author{
AF, Ahmad Gaus. Sang Pelintas Batas \\ Biografi Djohan Effendi Jakarta: \\ ICRP dan Kompas, 2009.
}


Dewanto Nugroho, Iqbal Muhtarom. "Anti MUI: Islam Yes, MUI No, Surga Bukan Monopoli Muslim", Wawancara dengan Asghar Ali Engineer, Majalah Tempo, 20 Agustus 2008.

Effendi, Djohan. "Memikirkan Kembali Asumsi Pemikiran Kita", Kata Pengantar: Asghar

Ali Engineer: Islam dan Pembebasan, dalam

http://media.isnet.org/islam/Etc/P engantar.

Engineer, Asghar Ali. Islam dan Teologi Pembebasan, terj. Agung Prihantoro Yogyakarta: Pustaka Pelajar, 2003. Islam and Its Relevansi to Our Age, terj. Hairus Salim dan Imam Baehaqi, Yogyakarta: LkiS, 1993.

. Islam and Liberation Theology: Essays and Liberative Elements in Islam New Delhi: Sterling Publisher Private Limited, 1990.

- Hak-hak Perempuan dalam Islam, terj. Farid Wajidi Yogyakarta: Pustaka Pelajar, 2000.

Esha, Muhammad In Am. Rethinking Kalam: Sejarah Sosial Pengetahuan Islam, Mecermati Dinamika dan Arus Perkembangan Kalam Kontemporer Yogyakarta: eLSAQ Press, 2006.
Fanani, Muhyar. Metode Studi Islam Aplikasi Sosiologi Pengetahuan sebagai Cara Pandang Yogyakarta: Pustaka Pelajar, 2008.

Irmasari,

Dewi. https://news.detik.com/berita/d3468925/buya-syafii-bicara-soalsuriah-irak-dan-teologi-maut, diakses 5 November 2019.

Nuryatno, M. Agus. "Asghar Ali Engineer: Sang Teolog Pembebasan", dalam http://www.mailarchive.

com/kmnu2000@yahoogroups.co $\underline{\mathrm{m} / \mathrm{msg} 01}$.

Putra, Rido. "Pemikiran Farid Esack tentang Hermeneutika Pembebasan" dalam Abdul Mustaqiem (ed.), Studi al-Qur'an dan Hadis Perspektif Teks dan Konteks Yogyakarta: FA Press, 2018.

Pieris, Aloysius. An Asian Theology of Liberation New York: Orbis Books Maryknoll, 1988.

Syarif, Jamal. "Pemikiran Asghar Ali Engineer Tentang Hak-Hak Perempuan dalam Islam", Khazanah Jurnal Ilmiah Keislaman dan Kemasyarakatan, Vol. III, No.1, Januari-Pebruari 2004, Banjarmasin: IAIN Antasari, 2004. 